\title{
PENDIDIKAN KELUARGA SEBAGAI MANIFESTASI BASIC NILAI- NILAI PLURALISME DI DUKUH KALIPURU KENDAL
}

\author{
Dudung Hamdun
}

Dosen UIN Sunan Kalijaga Yogyakarta

Email: hamdundudung123@gmail.com

\begin{abstract}
ABSTRAK
International NGO Forum on Indonesian Development (INFID) dalam surveinya tentang persepsi dan sikap generasi muda terhadap radikalisme dan ekstrimisme kekerasan, menyatakan bahwa peran orang tua sangat penting dalam pendidikan agama. Orang tua atau keluarga mempunyai peranan yang amat penting dalam mempengaruhi pendidikan anaknya. Di keluarga orang tua tidak hanya memberikan pengetahuan dalam aspek kognitif, melainkan juga aspek psikomotorik dan afektif. Pendidikan keluarga ranah yang paling efektif untuk mendidik anak dan menyalurkan ide dan gagasan terlebih soal keagamaan. Penelitian ini bertujuan untuk mengetahui korelasi antara pendidikan keluarga dengan penanaman nilai-nilai pluralism serta menjelaskan potret pendidikan keluarga di Kalipuru.
\end{abstract}

\section{Kata Kunci: Pendidikan Keluarga, Nilai-nilai Pluralisme, Dukuh Kaliparu}

\begin{abstract}
The International NGO Forum on Indonesian Development (INFID) in its survey of young people's perceptions and attitudes toward radicalism and violent extremism, stated that the role of parents is very important in religious education. Parents or families have a very important role in influencing the education of their children. In the family parents not only provide knowledge in the cognitive aspect, but also the psychomotor and affective aspects. It is the most effective education of the sphere to educate children and channel ideas and ideas on religious matters. This study aims to determine the correlation between family education with pluralism values and explains the portrait of family education in Kalipuru.
\end{abstract}

Keywords: Family Education, Pluralism Values, Dukuh Kaliparu 


\section{PENDAHULUAN}

Indonesia yang mempunyai semboyan Bhineka Tunggal Ika yang berarti "Berbedabeda tetapi tetap satu", ternyata masih banyak terjadi kasus kekerasan yang mengatasnamakan agama. Pada Agustus 2012, warga Islam Sunni mengusir warga Islam Syiah, karena menganggap bahwa Syiah adalah sesat. ${ }^{27}$ Setelah kejadian tersebut, banyak di daerahdaerah lain juga melakukan hal yang hampir sama, dengan cara memasang spanduk "Syiah Bukan Islam".

Setelah kasus Syiah, pada 2015 terdapat kasus konflik yang mengatasnamakan agama. Tanggal 7 Juli 2015, Mushalla di Tolikara dibakar. Kasus terbaru terjadi pada 13 Oktober 2015, beberapa Gereja di Desa Suka Makmur, Gunung Meriah, Singkil, Aceh dikabarkan dibakar oleh massa. ${ }^{28}$ Fenomena konflik tersebut seharusnya tidak terjadi pada antar umat beragama. Mengingat bahwa puncak keberagaman seseorang adalah adanya etika dan moralitas dalam pribadi orang yang beragama. Seperti halnya Agama Islam, Nabi Muhammad SAW diutus di muka bumi ini untuk menyempurnakan akhlak yang tinggi.

Agama merupakan sebuah doktrin yang menyejarah. Pemikiran keagamaan senantiasa sering dan sejalan dengan dinamika sejarah pemikiran atau peradaban umat manusia. Tanpa itu, agama akan menfosil dan akan ditinggalkan oleh penganutnya. Perubahan pemikiran itu juga menyangkut tentang hal ikhwal yang

27 http://www.suarapembaruan.com/home/inilahkronologi-kekerasan-warga-syiah

28 http://m.tempo.co/read/ news/2015/10/16/063709964/beginikronologi-penyerangan-gereja-aceh-singkil berkaitan dengan konsep multikultural. ${ }^{29}$

Pemikiran keagamaan yang berorientasi pada multikulturalisme juga mengalami dinamika. Banyak even-even yang diselenggarakan lembaga keagamaan yang menggelar kesenian yang jarang terjadi pada kelompoknya, menggambarkan dinamika pemikiran tentang multikulturalisme. Pluralism dan multikulturalisme memang harus dikembangkan, agar konflik-konflik yang mengatasnamakan agama tidak marak terjadi di Indonesia.

Berkembangnya pluralisme dan multikulturalisme banyak memberikan kedamaian dan ketenteraman bagi umat beragama. Dengan adanya perkembangan pluralisme dan multikulturalisme, Prof. Dr. Tobroni, M.Si. berpendapat akan memberikan dampak: pertama, mengurangi pemikiran dan sikap beragam. Sikap mengedepankan perbedaan, saling menyesatkan akan dihindari, karena dapat menimbulkan kerugian. Kedua, dakwah agama yang selama ini bersifat memperbanyak jumlah pengikut dengan cara mengkonversikan pemeluk agama lain ke dalam agamanya, ke arah peningkatan kualitas pengalaman agama masing-masing.

Hubungan antar umat beragama dalam konteks peace keeping dan peace building adalah kedewasaan beragama. Sikap toleransi dan multikulturalisme pada umumnya dapat diterima oleh mereka yang memiliki kedewasaan beragama secara pribadi dan tidak dikaitkan dengan persoalan politik atau kepentingan-kepentingan tertentu. Kedewasaan beragama bukan sekadar inklusivisme terhadap agama lain, melainkan memiliki sikap penuh

29 Prof. Dr. Tobroni, M.Si., Relasi Kemanusiaan dalam Keberagama: Mengembangkan Etika Sosial Melalui Pendidikan ((Bandung: CV. Karya Putra Darwati, 2012), hlm. 70. 
kebijaksanaan (bil-hikmah), tutur kata yang lemah lembut penuh ketawadlu'an (almau'dloh hasanah), serta kemampuan berdialog dengan orang atau kelompok yang berbeda dengan argumen yang kuat dan menimbulkan pencerahan (wajadilhum bi-alati hiya ahsan). ${ }^{30}$

Peneliti dalam hal ini tertarik untuk menggali lebih mendalam bagaimana proses pluralisme dalam masyarakat. Sehingga kehidupan antar umat beragama tanpa adanya konflik dan persoalan. Pemahaman pluralism pastinya bukan langsung tiba-tiba muncul dalam diri seseorang, pastinya ada yang membentuk sehingga mempunyai pemahaman pluralism.

Peneliti kali ini mengangkat judul "Pendidikan Keluarga Sebagai Manifestasi Basic Nilai-Nilai Pluralisme Agama di Dukuh Kalipuru Kendal”. Penelitian ini memotret bagaimana pluralisme yang terjadi di Dukuh Kalipuru Kendal. Serta, penelitian ini juga akan mengkaji bagaimana pembentukan masyarakat sehingga mempunyai pemahaman tentang pluralism.

Kampung di Dukuh Kalipuru, Desa Kalirejo, Kecamatan Singorojo, Kabupaten Kendal, Jawa Tengah, berdasarkan liputan Kompas, merupakan salah satu contoh potret keberagaman yang terbangun dalam masyarakat. Perbedaan agama dan keyakinan tidak menjadi persoalan yang mendasar dalam kehidupan sosial di sana. Perbedaan dikelola dengan baik, hingga memunculkan rasa saling menghormati.

Di sepanjang jalan 500 meter Dukuh Kalipuru berjejer empat rumah ibadah, satu di antaranya berdiri berdampingan. Masjid atTaqwa untuk umat Islam, Gereja Kristen Jawa (GKJ) Boja untuk warga Kristen, Musholla Suwuan untuk Islam dan Pura Sita Nirmala Jati

$30 \quad$ Ibid; hlm. 75-76. untuk warga Hindu. Penghayat pun dapat hidup berdampingan dengan mereka. Kehidupan masyarakat yang heterogen, mempunyai agama yang berbeda-beda ternyata tidak menjadi persoalan.

Berdasarkan data yang dilangsir dari liputan Kompas Bulan Juli 2015, menurut tokoh Kristen, Supriyanto, salah satu kunci sukses hidup berdampingan adalah dengan saling memahami. Sejak kecil, anak-anak maupun orang dewasa sudah diajarkan toleransi beragama, pluralism, dan saling menghormati. Anak-anak di Dukuh Kalipuru tidak pernah diajarkan untuk saling menghina satu agama dengan agama lain.

Marsudi, Kepala Desa Kalirejo berpendapat yang sama. Agama dan kepercayaan yang diyakini masyarakat Kalipuru memberikan arah bertindak yang baik. Keyakinan agama menurut Marsudi menjadi salah satu sarana untuk rem dan kontrol pada perbuatan yang tidak baik. Keluarga mempunyai peran penting, menurut Marsudi. Masyarakat tetap rukun karena kerukunan dibangun sejak keluarga.

Atas dasar itulah, peneliti akan mengkaji pendidikan seperti apa yang ditanamkan oleh anak-anak sehingga masyarakat memahami pluralisme, rukun antar umat beragama. Penelitian ini nantinya akan menggali dan menemukan strategi pendidikan keluarga yang efektif untuk menanamkan nilai-nilai pluralisme. Jika keluarga-keluarga lain menerapkan pola didik yang sama di Kalipuru, nantinya kemungkinan-kemungkinan besar konflik yang membawa nama agama tidak akan terjadi lagi.

\section{Pendidikan Keluarga dan Pluralisme}

Tiga tempat pendidikan yang dapat membentuk anak menjadi manusia seutuhnya adalah di keluarga, sekolah, dan masyarakat. Keluarga merupakan titik tolak perkembangan 
kepribadian anak yang cerdas, sehat, dan memiliki penyesuaian sosial yang baik. Keluarga merupakan salah satu faktor penentu utama dalam perkembangan kepribadian anak, di samping faktor-faktor yang lain. Dikutip oleh Lazarus, Freud mengatakan bahwa pengaruh lingkungan keluarga terhadap perkembangan anak merupakan titik tolak perkembangan kemampuan atau ketidakmampuan penyesuaian anak. Menurutnya pula, periode ini sangat menentukan dan tidak dapat diabaikan oleh keluarga. ${ }^{31}$

Pendidikan secara umum merupakan aktivitas yang membentuk kehidupan manusia agar dapat mengoptimalkan kemampuannya layaknya manusia dengan panca indranya. Pendidikan menurut Undang-Undang Republik Indonesia Nomor 20 Tahun 2003 tentang sistem Pendidikan Nasional lengkap dijelaskan. Bahwa pendidikan merupakan usaha sadar dan terencana untuk mewujudkan suasana belajar dan proses pembelajaran agar peserta didik secara aktif mengembangkan potensi dirinya untuk memiliki kekuatan spiritual keagamaan, pengendalian diri, kepribadian, kecerdasan, akhlak mulia, serta keterampilan yang diperlukan dirinya, masyarakat, bangsa dan negara.

Willian J. Goode (1995) memberikan tanggapan, keberhasilan atau prestasi yang dicapai siswa dalam pendidikannya sesungguhnya tidak hanya memperhatikan mutu dari institusi pendidikan saja, tetapi juga memperlihatkan keberhasilan keluarga dalam memberikan anak-anak mereka persiapan yang baik untuk pendidikan yang dijalani. Pendidikan karakter yang paling utama dan bisa diandalkan letaknya adalah pada keluarga.

31 Dr. Helmawati, .E., M.Pd.I. Pendidikan Keluarga: Teoritis dan Praktis (Bandung: PT Remaja Rosdakarya, 2014) hlm. 49.
Sehingga keluarga peran aktif untuk mendidik anaknya sangat diharapkan

Dengan begitu, pendidikan keluarga merupakan aktivitas pembelajaran secara aktif oleh orang tua kepada anaknya. Dengan proses pembelajaran di keluarga, anak dapat mengembangkan potensi dirinya, yaitu memiliki pemahaman keagamaan, pengendalian diri, kepribadian, kecerdasan, akhlak mulia, serta keterampilan yang diperlukan dirinya, masyarakat, bangsa dan negara.

Materi yang dijadikan bahan ajar proses pembelajaran di keluarga harus menyesuaikan dengan kebutuhan dan tujuan pendidikan itu sendiri. Orang tua sebagai pendidik yang pertama, harus tahu materi apa yang akan diberikan dan dibutuhkan oleh anak-anaknya. Menurut Helmawati dalam bukunya Pendidikan Keluarga menjelaskan, asas atau dasar materi pendidikan yang akan diberikan kepada anak hendaknya pada asas agama, asas falsafah, asas psikologi, dan asas sosial. Pendidikan yang berasaskan agama akan membantu anak untuk memiliki iman yang kuat kepada Tuhan Yang Maha Esa sehingga anak akan mampu membedakan mana yang baik dan buruk serta mampu menjalankan perintah dan menjauhi larangan-larangan-Nya. Pendidikan agama akan membentuk akhlak mulia serta menjadi manusia yang produktif.

Materi yang disampaikan di pendidikan keluarga dapat melihat konsep tokoh-tokoh pendidikan, terutama konsep pendidikannya Ibnu Sina. Secara garis besar kurikulum yang dikenalkan Ibnu Sina memiliki tiga ciri. ${ }^{32}$ Pertama, kurikulum berisi sejumlah mata pelajaran yang disertai dengan tujuan dari masing-masing mata pelajaran tersebut, di samping mempertimbangkan juga faktor

$32 \quad$ Ibid., hlm. 54 
psikologis dan perkembangan jiwa anak, yakni minat, bakat, dan keahlian yang akan dikembangkan, dan kapan masing-masing mata pelajaran tersebut disajikan.

Kedua, kurikulum bersifat pragmatis fungsional yang berorientasi pada kebutuhan pasar agar anak nantinya siap difungsikan dalam berbagai lapangan pekerjaan di masyarakat. Ketiga, kurikulum bersifat empirik, yang sangat dipengaruhi oleh pengalaman pribadinya, karena Ibnu Sina menghendaki agar setiap orang yang mempelajari berbagai ilmu dan keahlian menempuh cara sebagaimana yang ia lakukan.

Berdasarkan uraian konsep materi yang dipaparkan oleh Ibn Sina, pakar pendidikan Islam, dapat dirumuskan bahwa materi pendidikan yang hendaknya diberikan dalam keluarga diklasifikasikan berdasarkan tingkatan usia, bakat atau potensi yang dimiliki, dan kejiwaan anak didik. Materi dalam keluarga dapat berupa:

1) Pelajaran keimanan (tauhid).

2) Pelajaran ibadah (sembahyang).

3) Pelajaran akhlak (kesopanan).

4) Pelajaran jasmani (olahraga), kesehatan, dan kebersihan.

5) Pelajaran membaca, menulis, dan berhitung.

6) Pelajaran bahasa.

7) Pelajaran kesenian.

8) Pelajaran Kitab Suci.

9) Ilmu terapan, seperti ilmu fisika dan matematika.

10) Ilmu praktis terapan, seperti keterampilan menenun membatik, mengelola uang, dan sebagainya.

Proses pendidikan antara orang tua dan anak hendaknya diselenggarakan secara interaktif, menyenangkan, menantang, dan juga memotivasi. Metode pendidikan yang digunakan dalam pendidikan di keluarga hendaknya bervariasi sesuai dengan potensi anak dan banyak memotivasi. Dalam proses pendidikan, metode sangat penting karena pada diri anak terdapat dua potensi, yaitu potensi positif dan negatif. Oleh karena itu, dalam diri anak ini dengan dua jalan. Pertama, proses mendidik anak dengan bersifat positif. Kedua, proses mendidik anak dengan bersifat penjagaan. ${ }^{33}$

Pluralisme berasal dari bahasa Inggris yang berakar dari kata "plural" mempunyai arti banyak atau majemuk. Secara istilah, pluralisme bukan sekadar keadaan atau fakta yang bersifat plural, jamak, atau banyak. Lebih dari itu, pluralisme secara substansional termanifestasi dalam sikap untuk saling mengakui sekaligus menghargai, menghormati, memelihara, dan bahkan mengembangkan atau memperkaya keadaan yang bersifat plural, jamak, atau banyak. $^{34}$ Martin H. Manser dalam Oxford Learner's Pocker Dictionary: "Plural (form of a word) used of referring to more than one". ${ }^{35}$

Alwi Shihab memandang pluralisme dapat disimpulkan menjadi 3 yaitu: pertama, pluralism tidak semata menunjuk pada kenyataan tentang adanya kemajemukan. Namun, yang dimaksud pluralisme adalah keterlibatan aktif terhadap kenyataan kemajemukan tersebut. Kedua, pluralisme harus dibedakan dengan kosmopolitanisme. Kosmopolitanisme

33 Ibid., hlm. 59.

34 Ngainun Naim dan Achmad Sauqi, Pendidikan Multikultural Konsep dan Aplikasi, (Yogyakarta: Ar-Ruzz Media, 2008), hlm. 75

35 Mersen, Martin H, Oxford Leaner's Pocket Dictionary, (Oxford University, 1999), Third Edition, hlm. 329 
menunjuk suatu realitas di mana aneka ragam ras dan bangsa hidup berdampingan di sautu lokasi. Maksudnya walaupun suatu ras dan bangsa tersebut hidup berdampingan tetapi tidak ada interaksi sosial. Ketiga, konsep pluralisme tidak disamakan dengan relativisme. Paham relativisme menganggap "semua agama adalah sama". Keempat, pluralisme agama bukanlah sinkretisme, yakni menciptakan suatu agama baru dengan memadukan unsur tertentu atau sebagian komponen ajaran dari beberapa agama untuk dijadikan bagian integral agama tersebut. ${ }^{36}$

Sedangkan menurut Moh. Shofan, pluralisme merupakan upaya untuk membangun tidak saja kesadaran normatif teologis tetapi juga kesadaran sosial, di mana kita hidup di tengah masyarakat yang plural dari segi agama, budaya, etnis, dan berbagai keragaman sosial lainnya. Karenanya, pluralisme bukanlah konsep teologis semata, melainkan juga konsep sosiologis. ${ }^{37}$

\section{Pluralisme Agama}

Pluralisme agama mempunyai dua arti, yaitu pluralisme agama dalam arti teologis dan prluralisme agama dalam arti sosiologis. Pluralisme agama menurut Sjafril (2011:70) mengungkapkan bahwa istilah pluralisme agama menunjuk pada sebuah sistem yang mengakui koeksistensi keagamaan kelompok, baik yang bercorak ras, suku, aliran maupun partai dengan tetap menjunjung tinggi aspekaspek perbedaan yang sangat karakteristik di antara kelompok-kelompok.

36 Alwi Shidab, Islam Inklusif Menuju Sikap Terbuka (Bandung: Mizan, 1999) hlm. 39.

37 Moh. Shofan, Menegakkan Pluralisme: Fundamentalisme Konservatif di Tubuh Muhammadiyah (Jakarta: LSAF, 2008) hlm. 87.
Pluralisme agama dalam arti teologis diungkapkan oleh John Hick, Hikmah Abadi, aliran Humanisme Sekuler dan TeosofiFreemansory. Menurut John Hick (dalam Sjafril, 2011: 74) bahwa agama-agama yang ada sebenarnya menyembah Tuhan yang sama, namun melihat dari perspektif dan jarak yang berbeda, sebagaimana planet-planet dalam tata surya mengitari bintang yang sama dengan orbit yang berbeda-beda.

Sedangkan menurut Nurcholis Madjid, pluralisme agama tidak dapat dipahami hanya dengan mengatakan masyarakat kita majemuk, beraneka ragam, berdiri berbagai suku dan agama yang justru hanya menggambarkan kesan fragmentasi bukan pluralisme. Pluralisme agama harus dipahami sebagai pertalian sejati kebhinekaan dalam ikatan-ikatan keadaban (genuine engagement of diversities whin the bond of civility). ${ }^{38}$

Dari banyak pendapat, pluralisme agama merupakan pertalian sejati kebhinekaan, pemeluk agama tituntut bukan hanya mengakui keberadaan dan hak agama lain, tetapi terlibat dalam usaha memahami perbedaan dan persamaan guna tercapainya kebhinekaan.

Menurut Kosuke Koyama, sejauh ini perbincangan mengenai pluralisme keagamaan berkaitan dengan dua pendekatan terhadap watak dan hakikat kebenaran; pertama, kelompok yang mengatakan bahwa sejak semula hakikat kebenaran tidak hanya satu, melainkan banyak. Pandangan ini dapat disebut sebagai pluralisme ekstrim. Kedua, kelompok yang berpandangan bahwa hanya ada satu hakikat kebenaran yang muncul dalam banyak bentuk. Pandangan ini dapat disebut pluralisme moderat. Melalui kajian terhadap beberapa

38 Budi Munawar Rachman, Islam Pluralis, (Jakarta: Paramadina, 2001), hlm. 39 
referensi dapat ditemukan tipologi pandangan para ahli yang dapat dikelompokkan dalam pluralisme yang ekstrim atau moderat. ${ }^{39}$

Tipologi yang dibuat Koyama tersebut semakin mempertegas pandangan yang menginginkan agar pluralisme juga mengakui: (1) beberapa common ground di mata semua kemanusiaan berdiri, yang tanpanya maka berbagai model keberagaman seperti pluralisme, inklusivisme, dan ekslusivisme tidak akan pernah bermakna, (2) kebenaran yang sama dapat muncul dalam tradisi agamaagama yang berbeda melalui simbol-simbol dan bentuk-bentuk pemikiran, (3) apa pun yang dikatakan orang mengenai pluralisme, inklusivisme, dan eksklusivisme, yang pasti kehidupan keagamaan adalah suatu komitmen. Orang Kristiani adalah kristiani karena meyakini Kristen sebagai agama yang benar, demikian juga meyakini Kristen sebagai agama yang benar demikian juga dengan orang Islam, Hindu, Budha, dan seterusnya. ${ }^{40}$

\section{METODE PENELITIAN}

Penelitian ini menggunakan penelitian kualitatif. Penelitian kualitatif menurut Sukadinata (2009: 94) merupakan penelitian ditujukan untuk memahami fenomenafenomena sosial dari sudut atau perspektif partisipan. Partisipan merupakan orang-orang yang diajak berwawancara, diobservasi, diminta memberikan data, pendapat, pemikiran dan persepsinya.

Penelitian ini menggunakan desain penelitian studi kasus. Studi kasus menurut Stake, pilihan terhadap objek penelitian, bukan

39 Dr. Biyanto, M.Ag, Pluralisme Keagamaan dalam Perdebatan. (Malang: UMM Press, 2009), hlm. 44

$40 \quad$ Ibid., hlm. 45. konsekuensi metodologis. Kasus-kasus yang dipilih mungkin bersifat sederhana, mungkin juga rumit dan kompleks. ${ }^{41}$ Menurut Robert, K. Yin dalam Imam Suprayogo, mengemukakan bahwa studi kasus secara teknik berupaya: 1) menyelidiki fenomena kontemporer dalam konteks kehidupan nyata; bila 2) batas-batas antara fenomena dan konteks tak tampak dengan tegas; 3) mulai sumber bukti dimanfaatkan.

Penelitian ini diselenggarakan di daerah Dukuh Kalipuru, Desa Kalirejo, Kecamatan Singorojo, Kabupaten Kendal, Jawa tengah. Alasan memilih tempat ini sebagai objek penelitian karena di wilayah Dukuh Kalipuru sebagai representasi daerah yang menjunjung tinggi pluralisme agama. Masyarakat di sana hidup rukun dan saling menghormati antar umat beragama, bahkan rumah ibadahnya saling berdekatan. Oleh karenanya, penelitian ini dilaksanakan di daerah ini agar bisa menginspirasi daerah lain yang juga terdapat bermacam-macam agama untuk bisa hidup rukun dan menjunjung kebhinekaan dan nilainilai pluralisme agama.

Waktu penelitian adalah lamanya waktu yang diperlukan untuk kegiatan penelitian sebagai langkah awal. Selanjutnya pengambilan data hingga pengolahan data, revisi dan penggandaan hasil penelitian, hingga publikasi.

Fokus penelitian ini adalah ingin mengungkapkan bagaimana pendidikan keluarga dapat membentuk pemahaman masyarakat tentang nilai-nilai pluralisme agama. Sehingga masyarakat hidup rukun dan tanpa ada konflik gara-gara perbedaan agama dan pendapat. Selain itu, penelitian ini juga

41 Prof. Dr. Nyoman Kutha Ratna, SU. Metodologi Penelitian: Kajian Budaya dan Ilmu Sosial Humaniora pada Umumnya, (Yogyakarta: Pustaka Pelajar, 2010), hlm. 190. 
akan menarasikan pluralisme seperti apa yang terdapat di Dukuh Kalipuru serta bagaimana pola pendidikan keluarga.

Kehadiran peneliti dalam penelitian ini bersifat pasif, karena hanya mengamati keadaan sebenarnya. Kemudian peneliti melakukan wawancara kepada informan dengan memberikan pertanyaan yang berhubungan dengan pluralisme agama di daerah Dukuh Kalipuru, Kendal, Jawa Tengah. Peneliti juga meminta dokumen dan kependudukan dan foto kegiatan masyarakat. Maka pada dasarnya kehadiran peneliti di sini di samping sebagai instrumen juga menjadi faktor penting dalam seluruh kegiatan penelitian ini.

Subjek penelitian dalam penelitian ini adalah masyarakat di Daerah Dukuh Kalipuru, Kendal, Jawa Tengah yang diambil dengan menggunakan purposive sampling. Menurut Patton (dalam Imam Suprayogo. 2001: 165) Purposive sampling merupakan memilih informan yang dianggap mengetahui informasi dan masalah secara mendalam dan dapat dipercaya untuk menjadi sumber data yang mantap. Bahkan dalam pelaksanaan pengumpulan data, pilihan informan dapat berkembang sesuai dengan kebutuhan dan kemantapan peneliti dalam memperoleh data.

Berdasarkan teori Patton, maka kriteria informan dalam penelitian adalah:

1. Penduduk di daerah Dukuh Kalipuru yang tinggal selama minimal sepuluh tahun.

2. Pemuka agama, karena pemuka agama memahami budaya serta pluralitas keagamaan yang ada pada daerah tersebut. Sehingga bukan sekadar mengetahui, tetapi benar-benar meresapi dan memahami budaya dan pluralitas agama di masyarakat daerah Kembang Jepun.
Teknik pengumpulan data dalam penelitian ini menggunakan wawancara mendalam. Wawancara mendalam meliputi menanyakan pertanyaan dengan format terbuka, mendengarnya dan merekamnya, dan kemudian menindaklanjuti dengan pertanyaan tambahan yang terkait. Selain itu data juga dikumpulkan dengan observasi partisipan. Observasi partisipan yaitu peneliti melakukan penelitian dengan cara terlibat langsung dalam interaksi dengan objek penelitiannya. Dokumentasi digunakan untuk menjawab berbagai pertanyaan atau informasi untuk penelitian.

Penelitian ini mengungkapkan analisis data seperti yang diungkapkan Tjejep Rohendi Rohidi, ada tiga komponen dalam teknik analisis data, yaitu:

1. Reduksi data adalah pemilihan, pemusatan perhatian pada penyederhanaan, pengabstrakan dan transformasi data kasar yang muncul dari lapangan.

2. Penyajian data adalah kumpulan informasi tersusun yang memberi kemungkinan adanya penarikan kesimpulan dan pengambilan tindakan.

3. Verifikasi adalah kegiatan di mana kesimpulan yang ada dan belum jelas diverifikasi agar dapat dipahami dan dipertanggungjawabkan.

Pengecekan keabsahan data hasil penelitian menggunakan trigulasi, Trigulasi merupakan salah satu metode yang paling umum di pakai dalam uji validitas penelitian kualitatif. Di mana kebenaran bukan terletak pada peneliti, melainkan realitas objek itu sendiri.

Penelitian ini menggunakan teknik trigulasi metode untuk melakukan pengecekan 
keabsahan hasil penelitian. Trigulasi yaitu penggunaan berbagai metode untuk meneliti suatu hal seperti metode wawancara, metode observasi, dan metode dokumentasi.

\section{PEMBAHASAN}

\section{Pendidikan Keluarga di Kalipuru Menurut Pandangan Tokoh Masyarakat}

Marsudi, Kepala Desa Kalirejo dan kebetulan ia adalah warga Kalipuru. Ia merupakan kepala desa yang sudah menjabat dua priode. Pada 2016, saat peneliti menemuinya adalah masa jabatan yang priode kedua kalinya. Marsudi menjadi narasumber pertama, mengingat ia adalah kepala desa, darinya peneliti menemukan narasumbernarasumber yang untuk diwawancarai..$^{42}$

Sebelumnya, Marsudi menjelaskan bahwa keluarga di Dukuh Kalipuru mempunyai peranan yang penting dan strategis untuk menanamkan nilai-nilai pluralisme agama. Saat diwawancarai, ia mengakui bahwa di dusun Kalipuru terdapat empat tempat ibadah dalam satu dusun. Terdiri dari dua tempat ibadah Islam, masjid dan mushola. Kemudian, Gereja dan vihara.

Terkait pendidikan keluarga, Marsudi menjelaskan bahwa orang tua membiarkan anaknya berkembang sendiri. Peran orang tua adalah mengontrol jika tindakan anaknya

42 Wawancara dengan Marsudi, Kepala Desa Kalirejo dan Tokoh masyarakat di Kalipuru pada 29 Juli 2016. Marsudi merupakan sumber pertama yang ditemui oleh peneliti untuk menemukan narasumber-narasumber primer. Peneliti melakukan wawancara pada pukul 09:30-11:30 pada hari Jum'at 29 Juli 2016. Peneliti menemui Marsudi dengan maksud, pertama meminta izin penelitian di Dukuh Kalipuru Desa Kalirejo, dan wawancara terkait kondisi keberagaman dan pola pendidikan yang ada di Kalipuru. negatif. "Kalau ada yang negatif nantinya akan diarahkan oleh keluarga," jelasnya. Bahkan persoalan hubungan menikah beda agama di Dukuh Kalipuru menurut Marsudi tidak menjadi masalah. Orang tua merestui hubungan anaknya yang menikah dengan pasangannya yang berbeda agama.

Pernikahan antara dua pasangan yang berbeda agama tidak menjadi masalah. Hal tersebut terjadi di Dukuh Kalipuru. Orang tua memberikan kebebasan kepada anak-anaknya. Bahkan orang tua, menurut Marsudi, tidak pernah membatasi anak-anaknya bermain dengan temannya yang berbeda agama. Walaupun ada segelintir orang ada yang membatasi, menurut pengakuan Marsudi. Namun, mayoritas keluarga membebaskan anak-anaknya untuk bermain dan berkumpul dengan teman-temannya yang berbeda agama.

Pendidikan untuk saling menghormati sudah menjadi adat dan sudah tertanam di masyarakat Kalipuru. Menurut pengakuannya, kalau sudah bergaul dengan orang lain, sudah tidak membeda-bedakan agama. Ketika sudah berbaur dengan teman atau dalam perkumpulan, tidak pernah mempertanyakan agamamu apa. Di Karang Taruna, anggotanya terdiri dari berbagai latar belakang, tidak membedabedakan agama. "Di Karang Taruna, kita kerja bersama, kalau makan pun kita makan bersama" tandasnya. Ketika sedang masuk waktu ibadah, saling mengingatkan. Misalnya Islam, teman-temannya mengingatkan untuk menjalankan shalat terlebih dahulu. Dan ketika ada kegiatan bersama, ketika ada salah satu ritual keagamaan keseharian, akan dihargai dan diberikan waktu. Hal tersebut tidak menjadi masalah bagi pemeluk agama lain. Menurut Marsudi, di Kalipuru rasa saling mengormati sudah terbangun. 
Menurut pengakuannya, masyarakat di Kalipuru adalah orang yang nasionalis dan tidak fanatik. Pendidikan keluarga untuk menurunkan nilai-nilai pluralisme agama kuncinya adalah adat istiadat dipadukan dengan agama dan budaya, agar tidak salah mendidik generasi. Pendidikan keluarga dan masyarakat yang berasaskan adat istiadat dipadukan dengan nilai-nilai kejujuran, kebaikan tentang jati dirinya. Pendidikan tersebut dari keluarga yang menurunkannya.

Karnadi, merupakan tokoh masyarakat yang kedua peneliti datangi ketika di Dukuh Kalipuru. Ia sebagai tokoh masyarakat, posisinya di pemerintah desa adalah sebagai ketua Rukun Warga (RW). Di Kalipuru terdapat 1 RW dan 5 RT. Bapak dari dua anak ini merupakan salah satu tokoh yang mengetahui sejarah dusun Kalipuru.

Pendidikan keluarga sebagai manifestasi penanaman pluralisme agama di Kalipuru menurut pandangan Karnadi, ditransformasi melalui keluarga dan masyarakat. Keluarga sebagai kontrol terhadap anak, sedangkan budaya masyarakat mengajarkan saling menghormati dan rukun. Salah satu budaya yang mengajarkan pluralisme agama di Kalipuru adalah saling menghargai acara keagamaan. Karnadi mencontohkan, ketika ada hajatan salah satu warga, maka masyarakat yang berbeda keyakinan dan agama pun datang untuk berdoa bersama. Namun, sebelum mengundang dari masyarakat secara umum, ritual keagamaan dijalani terlebih dahulu oleh masyarakat yang satu agama. Kemudian, ada acara bersama untuk semua masyarakat termasuk pemeluk agama lain. Ponidjan, selain sebagai tokoh masyarakat, ia sebagai penandita Agama Hindu. Ia juga menjabat sebagai perangkat desa Kalirejo di bidang keuangan. Usianya yang sudah menginjak kepala tiga, ia masih semangat dalam menjalankan aktivitas keagamaan dan mengabdi untuk desa.

Pluralisme dan kerukunan beragama yang ada di Dusun Kalipuru bagi Ponidjan dipengaruhi juga oleh pendidikan keluarga. Pendidikan keluarga ikut andil dalam menjaga tradisi dan adat kerukunan di Kalipuru. Pendidikan keluarga di Dusun Kalipuru sama dengan pendidikan keluarga. Pendidikan yang mendidik generasi saling asah dan saling asih..$^{43}$

Ia juga tidak membatasi anak-anaknya untuk bermain dan mengikuti kegiatan di masyarakat, walaupun kegiatan keagamaan lain. Ponidjan mengaku, terkait bidang keagamaan, anaknya ikut kegiatan apa saja dia ikut. "Kegiatan pemuda muslim, nasrani dia ikut, tapi dia tetap Hindu," jelasnya. Ponidjan tidak melarang anaknya ketika mengikuti kegiatan walaupun kegiatan agama lain, seperti kegiatan agama Islam dan Kristen.

Ponidjan beranggapan, kalau anak sudah dewasa bisa memilih kebaikan dan kebenarannya sendiri. Ia tidak menyuruh untuk tetap pada pilihannya. Bahkan anaknya nikah secara Islam. Setelah menikah, Ponidjan memperjelas soal pilihan agamanya. Apa melanjutkan agama Islam atau tetap Hindu. Dan anaknya memilih masuk ke Hindu, lalu diberikanlah surat untuk masuk agama Hindu dan mengganti Kartu Keluarga dan KTP bahwa dia beragama Hindu.

Pendidikan masyarakat juga mengajarkan pada suatu hal yang baik. Pendidikan masyarakat juga mengajarkan kepada generasi muda pada kebaikan. Ponidjan mencontohkan, bahwa antar tetangga saling membantu dan saling memberi,

43 Wawancara dengan Tokoh Agama Hindu dan Tokoh Masyarakat Desa Kalirejo khususnya Dusun Kalipuru, Ponidjan. Wawancara dilakukan pada pulul 18:30-20:30 pada tanggal 30 Juli 2016 dikediamannya, suwukan Dukuh Kalipuru, Desa Kalirejo. 
walaupun memberi sayur atau bahan makanan kalau sedang ada rezeki yang lebih. "Kalau ada yang punya sayur, nanti saling memberi. Di sini punya beras dan di sana tidak punya beras, nanti saling mengutangi," tandasnya.

Dalam pendidikan keluarga menurut Ponidjan, disesuaikan dengan umur dan kedewasaan. Mendidik anak dengan mendidik orang dewasa berbeda. Mendidik anak bisa menggunakan metode lagu supaya anak bisa membiasakan hal-hal yang baik dalam keseharianya. "Kalau menasihati anak kelas satu, bangun tidur ku terus mandi, tidak lupa menggosok gigi, habis mandi ku tolong ibu, itu ajarannya orang tua," contoh Ponidjan.

Ponidjan yang juga sebagai ketua komite SD Kalirejo, dalam mendidik anak-anak supaya belajar yang benar. Ia selalu berpesan kepada pada generasi muda, kalau beragama Islam, Islamlah yang benar. Begitu juga ketika beragama Kristen, beragama Kristenlah yang baik. Ketika beragama Hindu, beragamalah yang baik. Ia membebaskan bagi anak-anaknya, milih agama mana itu haknya. Terpenting dalam kehidupan sosial masyarakat, bertindak dengan tatanan yang baik dan sesuai dengan aturan negara.

Dalam mendidik anak-anak atau generasi muda Kalipuru, bahwa ketika belajar kitab jangan diputus-putus. Kalau membaca kitab harus diselesaikan. Baginya, kalau membaca kitab diputus-putus menjadikan tidak benar. Dalam mendidik dan membina umat Hindu, ia tidak pernah menanamkan kebencian terhadap pemeluk agama lain.

Sama halnya dengan yang disampaikan oleh Sudarminto, tokoh masyarakat dan tokoh agama. Ia menganggap bahwa pendidikan keluarga sangat penting sekali. Anak harus mendapatkan pembekalan dari keluarga. Di antaranya adalah pembekalan kerukunan antar sesama teman tidak dan tidak membedabedakan agama.

Pendidikan kerukunan bagi Sudarminto perlu untuk ditanamkan di keluarga. Ketika pendidikan kerukunan ditanamkan, generasi muda tidak mudah fanatik dan tidak mudah membenci terhadap kelompok agama lain. Selain pendidikan keagamaan, ia juga menyarankan juga menjalankan penanaman nasionalisme. Nasionalisme yang dipraktikkan oleh Sudarminto dalam kehidupan keluarga yaitu dengan menjaga tradisi lokal, seperti selametan ketika membangun rumah dan setiap malam Jum'at mengadakan pertemuan rutin di rumah warga-warga untuk menjalankan tahlilan.

Berbeda dengan menurut pandangannya Supriyanto, salah satu tokoh Agama Kristen di Dusun Kalipuru. Ia mendidik dan memberikan pemahaman kepada anaknya tentang agama, bahwa agama adalah baju. Kalau kamu pakai baju merah, kuning, hijau, dan yang lainnya memakai baju lainnya tidak masalah. Pemahaman seperti itu juga diberikan oleh orang tua kepadanya. Tercermin dari beragammnya keluarga besar Supriyanto. Keluarga besarnya tidak semuanya beragama Kristen, melainkan ada yang Islam dan Hindu.

Bahkan anaknya Supriyanto bisa mengaji kitab suci Al-Qur'an dasar. Mengingat anaknya yang masih kelas dua Sekolah Dasar. Ketika terdengar suara adzan bahkan ia sering keluar untuk mengaji. Dia juga bisa menulis tulisan Arab.

Supriyanto beranggapan bahwa anak kecil belum tahu mendalam soal agama. Bahkan anaknya juga mengikuti doa yang dipakai orang Islam. Karena di sekolahnya tidak ada guru agama Kristen. Pendidikan perdamaian atau kerukunan diturunkan ke anak-cucunya di Dukuh kalipuru. Akibatnya, sampai saat ini 
dukuh Kalipuru damai rukun antar warga dan antar umat beragama.

Tidak jauh berbeda dengan pola pendidikan keluarga dari narasumber sebelumnya, Purwanto juga mempunyai pola pendidikan keluarga yang sama, yaitu mengajarkan kerukunan antar sesama namun dalam bingkai yang lain. Purwanto berbeda dengan narasumber lainnya. Dia adalah pendatang, 10 tahun sudah di dusun Kalipuru. Pastinya bagi pendatang ia mempunyai perspektif tersendiri dalam memandang suatu hal. Itu dugaan awal peneliti. Namun ketika diwawancarai, Purwanto mempunyai pandangan yang sama dengan narasumbernarasumber sebelumnya.

Baginya pendidikan keluarga menanamkan perilaku yang baik, jangan menyinggung umat beragama lain. Ia memesan kepada anak-anaknya agar menunjukkan perilaku beragama di masyarakat. Jangan pernah menjelek-jelekkan orang lain. Ia mengajari kepadanya, kalau ingin mengetahui agama lain, misalnya Islam disuruh datang ke pondok pesantren. Tujuannya, untuk bertanya tentang Islam bagaimana. Hal serupa dilakukan oleh Purwanto dengan istrinya, ia pernah belajar di pesantren Temanggung, mengingat dia juga fokus di ilmu perbandingan agama. Ia belajar di pesantren tentang perbedaan antara kiai dan haji.

Pendidikan masyarakat juga sangat berpengaruh baginya. Lingkungannya sangat beragam, ada yang beragama Hindu, Islam dan Katolik sebelum ia di Kalipuru. Oleh karenanya, ia dapat menyesuaikan dengan budaya yang ada di Kalipuru.

Penanaman orang tua kepada anaknya biar tidak menghina agama lain. Baginya, jangan memberikan suatu wejangan atau pengertian terhadap agama lain yang tidak benar, agar tidak timbul fanatik dan menjelek-jelekkan.
Contohnya, cara menyampaikan kepada anak, "Agama kan mempunyai adat istiadat masing-masing, setiap agama mempunyai kepercayaan masing-masing. Apa yang kamu lakukan dan tidak tahu kamu tanyakan, kalau dia bertanya kepadamu tentang agamamu, maka jawablah," tandasnya memberikan contoh.

Ia memesan kepada anak-anaknya, jangan sampai memperdebatkan panjang lebar tentang agama. Baginya, beda buku maka beda pula penafsirannya. Agama sama-sama mempunyai tujuan yang baik. Itu merupakan salah satu penanaman yang harus diberikan kepada anak. Bahkan saat Purwanto sedang ada acara, pemuda-pemuda di Kalipuru menawarkan untuk menjadi tukang parkir. Pemahaman seperti itu, menurut Purwanto tidak mudah dipahami oleh orang yang fanatik dan tidak mau mengerti serta tidak pernah mencari tahu.

Sumiyati adalah istri dari Purwanto. Pendidikan yang ditanamkan dalam keluarga difokuskan pada ke ajaran Hindu yaitu Srada atau keimanan. Iman yang kuat akan menuntun anaknya ke jalan yang lebih benar. Anak jika imannya yang kuat akan mengutamakan kebaikan dan toleransi. Ia selalu menanamkan kepada anak jangan sampai membedabedakan antara umat beragama, mengingat di Kalipuru terdiri dari berbagai macam agama. Ia memesan kepada anak-anaknya jangan sampai menjelek-jelekkan agama satu dengan agama lain, harus hidup rukun dan berdampingan. Dalam keluarga, ia juga menyarankan saling membantu antar sesama, tetangga dan keluarga dekat. Di mana saja, anak harus ditanamkan nilai-nilai Srada.

Sumiyati dan Purwanto mempunyai dua anak dan masih mengenyam pendidikan. Di sekolah, ia menanamkan untuk kebersamaan sesama teman. Walaupun anak-anaknya 
diajari untuk toleran, namun harus memegang prinsip keagamaan. Anak pertamanya yang sudah menginjak di Sekolah Menengah Pertama (SMP), ia dididik untuk memegang teguh prinsip keagamaannya. Ketika berdoa di dalam kelas, ia berdoa dengan menggunakan cara agamanya sendiri. Sumiyati yang juga guru agama Hindu di SD Kalipuru, mengajarkan kepada anaknya agar berani tampil di depan, misalnya untuk mempraktikkan cara berdoa orang Hindu.

Puja anak pertama dari Sumiyati, sejak TK sudah berani kalau ditanya agamanya apa, ia akan menjawab Hindu. Ia diajarkan oleh ibunya untuk menunjukkan nilai-nilai agama dengan tingkah laku sehari-hari. Puja juga pernah membuat puisi berdasarkan keadaan dia waktu di daerah Pakis Semarang. Ia hidup satu keluarga sendiri, namun setiap lomba dia yang mewakilinya. Bahkan banyak yang menangis ketika Puja membacakan puisi saat masih di Sekolah Dasar.

\section{Potret Pluralisme Agama di Dukuh Kalipuru}

Potret keberagaman di Dukuh Kalipuru unik karena di sana terdapat empat tempat ibadah dan ada tiga agama, rukun berdampingan. Sebagian masyarakat pun juga ada yang menganut aliran kepercayaan. Mereka tidak pernah mempersoalkan agama, dan tidak pernah membawa agama dalam ranah konflik sosial-kemasyarakatan.

Dusun Kalipuru berada di Desa Kalirejo Kecamatan Singorojo Kabupaten Kendal. Tempatnya begitu jauh dari perkotaan, harus masuk melalui hutan. Kalipuru merupakan salah satu dukuh di desa Kalirejo. Dukuh Klipuru merupakan dukuh yang paling jauh dari jalan raya desa Kalirejo.

Potret keberagaman di Dukuh Kalipuru bisa dilihat dari dua sisi. Pertama, adalah sisi fisik pembangunan tempat ibadah. Kedua, bisa dilihat dari kehidupan sosial kemasyarakatan. Kedua, hal saling berkaitan dan saling mendukung yang menyebabkan dukuh Kalipuru menjadi dukuh yang rukun.

Pertama, dari segi fisik, Dukuh Kalipuru terdapat 4 tempat ibadah. Empat rumah ibadah tersebut adalah Masjid at-Taqwa tempat ibadah umat Islam, Gereja Kristen Jawa Boja untuk umat Kristiani, Mushalla untuk umat Islam, kemudian Pura Sita Nirmala Jati untuk umat Hindu. Jarak antara Masjid ke Gereja adalah 100 meter. Kemudian jarak antara Gereja ke Mushalla adalah 250 meter. Sedangkan jarak Mushalla ke Pura adalah 200 meter.

Letak Masjid, Gereja, Mushalla dan Pura merupakan satu jalan, di tengah dusun Kalipuru. Ukuran dusun Kalipuru, terbilang lumayan banyak terdiri dari $1 \mathrm{RW}$ dan 5 RT. Ada tiga tokoh agama yang juga menjadi perangkat desa, yaitu Ponidjan sebagai tokoh agama Hindu, Supriyanto tokoh agama Kristen dan Sudarminto tokoh agama Islam. Sehingga pembangunan dan kegiatan agama dan sosial kemasyarakatan bisa berjalan dengan lancar. Ketiga tokoh tersebut dan tokoh lainnya sering berkoordinasi.

Kedua, dilihat dari sisi sosial kemasyarakatan, Dukuh Kalipuru juga menunjukkan pluralisme agama. Ada berbagai macam alasan, kenapa dukuh Kalipuru rukun dan hidup saling menghormati. Menurut penjelasan narasumber, Karnadi sebagai Ketua RW di Dukuh Kalipuru dan Sutrisno tokoh Agama Kristen serta Ponidjan tokoh agama Hindu dan Marsudi Kepala Desa Kalirejo, semuanya mengatakan bahwa di dusun Kalipuru hampir semuanya adalah saudara.

Hampir 90 persen masyarakat di Dusun Kalipuru ada kaitannya dengan hubungan keluarga. Menurut ceritanya Ponidjan dan Marsudi, dulu di Dusun Kalipuru awalnya warganya menganut kepercayaan. Namun setelah ada peraturan pemerintah harus 
mempunyai agama dan kepentingan administrasi, masyarakat mulai beragama. Agama pertama kali masuk adalah agama Islam. Namun menurut keterangan Sudarminto, awalnya masyarakat Kalipuru beragama Islam. Sumber yang ini tidak menjelaskan detail tahunnya kapan Islam masuk.

Masyarakat sana, baik yang beragama Islam, Kristen dan Hindu mempunyai corak yang sama yaitu mempertahankan kebudayaan jawa. Walaupun Islam, masih ada tradisi Jawa yang dipertahankan. Begitu juga dengan agama Kristen dan Hindu, mereka mempertahankan budaya jawa. Ada pula masyarakat yang menganut kepercayaan Jawa yang dibawa nenek moyangnya dulu di Kalipuru.

Masuknya Islam belum diketahui tahun berapa di Kalipuru. Agama Hindu masuk di Kalipuru pada tahun 1970-an. Agama Kristen masuk pada tahun 1980-an. Menurut Supriyanto dan Ponidjan, sejak masuknya agama Hindu dan Kristen tidak ada masalah dan tidak ada pertentangan dengan agama Islam yang masuk lebih dulu.

Seperti agama Kristen, masuk di Kalipuru dibawa oleh orang Kalipuru sendiri kemudian tersebar oleh keluarganya sendiri juga. Begitu juga dengan Agama Hindu, datang di Kalipuru dibawa oleh masyarakat Kalipuru sendiri. Berdasarkan cerita Ponidjan dan Karnadi, pada mulanya salah satu warga Kalipuru meminta petunjuk kepada orang lain luar desa, dan kebutulan yang dimintai petunjuk adalah orang Hindu, kemudian Hindu masuk ke Kalipuru.

Sejak pertama kali masuk di Kalipuru, pemeluk agama Hindu dan Kristen tidak ada pertentangan dengan pemeluk agama Islam. Secara umum, masyarakat Kalipuru tidak ada pertentangan yang mengatasnamakan agama. Atau gara-gara berbeda agama, tidak ada yang berkonflik antar masyarakat.

Bentuk keberagaman di Kalipuru terlihat dari berbagai hal:

1. Saling menghormati ketika salah satu umat beragama sedang menjalankan ritual keagamaan

2. Ketika salah satu warga yang meninggal, semua masyarakat ikut mengurusi dan mengantarkan jenazahnya, tidak membeda-bedakan agama

3. Ketika ada hari perayaan salah satu agama, pemeluk agama lain ikut merayakan dan datang dalam ritual keagamaan

4. Struktur rumah beragam, tidak terkotak-kotak per agama.

\section{KESIMPULAN}

Salah satu kunci sukses hidup berdampingan adalah saling memahami. Sejak kecil, anak-anak maupun orang dewasa sudah diajarkan toleransi beragama, pluralisme, dan saling menghormati. Anakanak di Dukuh Kalipuru tidak pernah diajarkan untuk saling menghina satu agama dengan agama lain. Masyarakat di dasa Kalipuru juga meyakini bahwa agama dan kepercayaan memberikan arah bertindak yang baik. Keyakinan agama menjadi salah satu sarana untuk rem dan kontrol pada perbuatan yang tidak baik. Keluarga mempunyai peran penting. Masyarakat tetap rukun karena kerukunan dibangun melalui keluarga. Orang tua atau keluarga mempunyai peranan yang amat penting dalam mempengaruhi pendidikan anaknya. Di keluarga orang tua tidak hanya memberikan pengetahuan dalam aspek kognitif, melainkan juga aspek psikomotorik dan afektif. Pendidikan keluarga ranah yang paling efektif untuk mendidik anak dan menyalurkan ide dan gagasan terlebih soal keagamaan. 


\section{DAFTAR PUSTAKA}

Shihab, Alwi. Islam Inklusif Menuju Sikap Terbuka. Bandung: Mizan, 1999.

Rachman, Budi Munawar. Islam Pluralis. Jakarta: Paramadina, 2001.

Biyanto. Pluralisme Keagamaan dalam Perdebatan. Malang: UMM Press, 2009.

Helmawati. Pendidikan Keluarga: Teoritis dan Praktis Bandung: PT Remaja Rosdakarya, 2014.

Mersen, Martin H. Oxford Leaner's Pocket Dictionary. Oxford University: Third Edition, 1999.

Shofan, Moh. Menegakkan Pluralisme: Fundamentalisme Konservatif di Tubuh Muhammadiyah. Jakarta: LSAF, 2008.

Naim, Ngainun dan Sauqi, Ahmad. Pendidikan Multikultural Konsep dan Aplikasi, Yogyakarta: Ar-Ruzz Media, 2008.

Ratna, Nyoman Kutha.. Metodologi Penelitian: Kajian Budaya dan Ilmu Sosial Humaniora pada Umumnya. Yogyakarta: Pustaka Pelajar, 2010.

Tobroni. Relasi Kemanusiaan dalam Keberagama: Mengembangkan Etika Sosial Melalui Pendidikan. Bandung: CV. Karya Putra Darwati, 2012.

http://www.suarapembaruan.com/home/inilahkronologi-kekerasan-warga-syiah

h t t p:// m.te m p o.co/ rea d / news/2015/10/16/063709964/beginikronologi-penyerangan-gereja-aceh$\underline{\text { singkil }}$ 
